\title{
Validation of Iron-Food Frequency Questionnaire for Assessing Iron Intake in Women of Reproductive Age: A Cross-Sectional Study on Female Undergraduate Students in Indonesia
}

\author{
Dimas Erlangga Luftimas ${ }^{1 *}$, Ardya Lucita ${ }^{2}$, Siska Wiramihardja ${ }^{1}$, \\ Viramitha Kusnandi Rusmil ${ }^{3}$ \\ ${ }^{1}$ Medical Nutrition Division, Department of Public Health, Faculty of Medicine, \\ Universitas Padjadjaran, Bandung 40161, Indonesia \\ ${ }^{2}$ Faculty of Medicine, Universitas Padjadjaran, Jatinangor 45363, Indonesia \\ ${ }^{3}$ Nutrition and Metabolic Division, Department of Child Health, Faculty of Medicine, \\ Universitas Padjadjaran, Bandung 40161, Indonesia
}

\begin{abstract}
The aim of this study is to develop and assess the validity of the Iron-Food Frequency Questionnaire (Iron-FFQ) in assessing the iron intake of reproductive age women. This cross-sectional study involved randomly selected female under graduate students at Jantinangor, Sumedang district, West Java $(\mathrm{n}=94)$ as respondents. The validity test compared the iron intake using Iron-FFQ with the 3-Days Food Diary (FD). The iron contents of each food from both methods were obtained from Indonesian Food Composition Table (2017). Iron contents were analyzed using the Wilcoxon signed rank test and Spearman's rank correlation. The results showed significant correlation in iron content between Iron FFQ and the 3 Days FD with $r=0.25$ for the tubers, nuts, and vegetables group, and $r=0.21$ for milk and fish $(\mathrm{p}<0.05)$. While, statistically non-significant correlations were found for the rest of the food groups (cereal, meat, poultry, eggs, fruits, fats, sugar, syrup, confectionary, and spices) with $\mathrm{r}$ ranged from $r=0.19$ to $r=0.01$. The average assessment value using Iron-FFQ was lower than the 3-Days Food Diary, especially in the food and beverages group (-100\%), sugar, syrup, and confectionary $(-93.8 \%)$, and vegetables (-88.5\%). In conclusion, Iron-FFQ can be declared valid for measuring iron intake from some food group such as starchy tubers, fish, shellfish and shrimp, nuts, vegetables, and milk as they have an acceptable correlation value.
\end{abstract}

Keywords: food frequency questionnaire, iron intake, reproductive age woman, validation study

\section{INTRODUCTION}

Women of reproductive age are those belong to 15-49 year old female group, either married or not (BKKBN 2015). Based on the 2017 Indonesia Health Profile, their number in Indonesia was $69,739,202$ or approximately $53.5 \%$ of all women (MoH RI 2018b). In addition to their reproductive roles, they have an important role in economic productivity (Pasricha et al. 2014). There is a massive increase in number of working women in Indonesia. There were 2.12 million working women in 2007 (Fitriananto et al. 2018), and based on the 2018 Profil Perempuan Indonesia, $48.12 \%$ of Indonesian women were working (Hakiki et al. 2018) or 52.33 million based on BPS Indonesia (BPS 2020).
Reproductive age women are prone to develop anemia and globally, 496 million $(29 \%)$ of non-pregnant women suffering from anemia (Pasricha et al. 2014), while in Indonesia the prevalence of anemia in the same group was $22.7 \%$ (MoH RI 2013). Further, the risk increased during pregnancy, in Indonesia 48.9\% of pregnant women were found anemic $(\mathrm{MoH}$ RI 2018a). Anemia increases the risk of low birth weight, postpartum bleeding and maternal mortality (Nechitilo et al. 2016). In addition, anemia in women of reproductive age can lead to restricted fetal growth and development, impeded immune, cognitive, motor and socialemotional development in children (Nechtilio et al. 2016). Thus meeting the nutritional needs of this demography will prevent nutrition related

\footnotetext{
"Corresponding Author: tel: +6282119131351, email: dimas.erlangga@unpad.ac.id

(Received 22-03-2021; Accepted 11-06-2021; Published 29-07-2021)
} 
diseases for themself and future generation (Perdana et al. 2014).

Iron plays an important role in human health and deficiency of this element in daily intake might result in iron deficiency anemia (Pasricha et al. 2014). According to the World Health Organization (WHO) publication in 2021, the most common causes of anemia include nutritional deficiency particularly iron (WHO 2021). Nutritional approach is can be an effective way to prevent iron deficiency anemia, hence assessment of iron intake is pivotal (Lopez et al. 2018). Therefore, establishing simple individual iron intake assessment tool is needed to support this stage (Głąbska et al. 2017). The Food Frequency Questionnaire (FFQ) is a tool that fits these assessments. This tool is easy, valid and can be used in large populations (Fahmida and Dillon 2011). However, few tools are specifically designed to assess iron intake (Głąbska et al. 2017). Therefore, the aim of this study is to assess the validity of Iron-FFQ to measure the iron intake in reproductive age women in West Java, Indonesia.

\section{METHODS}

\section{Design, location, and time}

This cross-sectional study was conducted between April and November 2018 at the Faculty of Medicine, Universitas Padjadjaran, Jatinangor campus. The research was conducted after obtaining permission from the Ethics Commission of the Faculty of Medicine, Universitas Padjadjaran with an approval number 959/UN6.KEP/EC/2018.

\section{Sampling}

Respondents who participated in this study were 100 students of the Faculty of Medicine, Universitas Padjadjaran batch 2016, 2017, and 2018. The research participants were recruited using systematic random sampling. A total of 505 female students were gathered as study population; 100 students who met the inclusion criteria and eliminated by the exclusion criteria were selected as study subject. The age range of respondents who participated in this study was 17-22 years. All of the participants had been provided with information and consented to participate in this study. The participants of this study were female undergraduate students of Universitas Padjadjaran, Jatinangor Campus, in the reproductive age range of 15-49 years (MoH RI 2018b). Students who were pregnant, had impaired red blood cell production or chronic diseases, lived with their parents, and were fasting when the data were taken were excluded. During the data quality control stage, it was found that 6 students were fasting or on a diet thus they were excluded and the final analysis only involved 94 participants.

\section{Data collection}

The data obtained in this study were general characteristics of respondents, respondents' anthropometry and iron intake obtained from the FFQ and Food Diary / Weighed Food Records. Standardization training for the data collection method was carried out by Nutrition Working Group Faculty of Medicine Universitas Padjadjaran.

We trained and briefed the respondents aiming for standardized result. On the first day, respondents was trained about, how to fill iron Food Frequency Questionnaire (FFQ), how to fill 3 days Food Diary (FD), including how to use the kitchen scale and assessed their anthropometry. At the end of the session respondents was given the FD and kitchen scale to be used at home. On the 8th day, respondents collected the FD back to the research team, re-briefed about how to fill the iron FFQ, then filled the FFQ.

Anthropometric measurement in this research included body height, body weight, and BMI. Body height measuring instrument used was SECA stadiometer and body weight was measured using digital scale Tanita SC240 following the protocol in Gibson's Nutritional Assessment 2005 (Gibson 2005).

Iron-FFQ was a food questionnaire which includes food and beverage list. The list was consisting of foods containing iron including both of raw and cooked food. The questionnaire was self-administered where respondents received a short briefing by the researcher beforehand which includes a mini trial. The questionnaire was immediately returned to the researcher after completion.

Food and beverages list in the questionnaire was developed from Food Diary (FD) which was collected in prior research conducted in 2017 (Anugerah 2018). Thirty-four FDs were collected. Raw and cooked food and beverage names were extracted and listed (132 items) in the FFQ. Foods and beverages included in the 
FFQ was those containing iron more than 0.1 mg per 100 grams of food (Gląbska et al. 2017) and base on Anugerah (2018) being consumed by more than $10 \%$ respondent $(n=34)$.

Food and beverages list obtained was then divided into 13 groups based on the Indonesian Food Composition Table 2017 (TKPI) (MoH RI $2018 \mathrm{c}$ ). The food groups were cereals and cereal products, starchy tubers and their processed products, meat, poultry and their processed products, fish, shellfish, shrimp and their processed products, nuts and their processed products, eggs and their processed products, vegetables and their processed products, fruits and their processed products, milk and their processed products, fats and their processed products, sugar, syrup and confectionery, spices, and drinks.

The portions served are based on most of the portions listed in the food diary which were previously used to list the names of food and drinks. Portions are served in the form of portions, pieces, packs, or other household sizes such as rice scoops, tablespoons. The frequencies used in this iron questionnaire are "never", "1 per month", "2-3 per month", "once a week", "2-4 times a week", "5-7 times a week", "Once a day", "2-3 times a day", "4-6 times a day", ">6 times a day" (Willet 1990).

Food Diary (FD) is chosen as a comparison tool. In the diary, there are empty columns which respondents can use to record every food and drink consumed. The columns consist of the schedule column for writing the day, date, and time; the food type column to write the food/ beverage and food ingredients, the amount that is served and wasted; and the last is the cooking method. To measure the amount of the weight served and wasted in grams, respondents were given a digital food scale, SF-400 kitchen scale, which has a capacity of up to $10 \mathrm{~kg}$ with a precision of $0.001 \mathrm{~kg}$.

Food Diary was distributed a week before FFQ. At the beginning, the researcher provided respondents with FD and digital food scales to help respondents in filling the diary. Respondents were asked to fill in this diary for 3 days, consisting of 2 working days or weekdays and 1 holiday or weekend. They were given 1 week to fill in this FD. Then, after a week the researcher returned to take the FD and the scales, and then gave IronFFQ to fill in. The mini trial was done in the time of FD and weighing scale distribution, and after briefed by Nutrition Working Group team from Faculty of Medicine Universitas Padjadjaran.

\section{Data analysis}

Iron content from food or drinks listed in these two methods was then measured using the Indonesian Food Composition Table 2017 (TKPI 2017). Mixed foods or drinks that were not listed in the TKPI 2017 or without iron content data were analyzed based on the ingredients and referring to TKPI 2017. Iron content was generated from total iron from each ingredient.

Iron-FFQ data were processed by converting the respondent-chosen frequency into daily frequency. Frequency was multiplied to foods or beverages portion in gram and the multiplied again to iron content per $100 \mathrm{~g}$, then divided to 100 . The result was stated with [daily frequency $\mathrm{x}$ food/beverages portion $\mathrm{x}$ portion weight $(\mathrm{g}) \mathrm{x}$ iron content per $100 \mathrm{~g}(\mathrm{mg}) / \mathrm{100})$ ]. After iron content was obtained from each food, the iron content average was calculated.

Furthermore, for FD, iron content from every food or drink listed in the form was collected. Just like the FFQ, the iron that had been obtained was then averaged according to the food group. After that, each food group from each day was calculated.

The data normality was tested using Saphiro-wilk. The mean difference between two iron intakes from both methods (each food group in FFQ and FD) was tested using Wilcoxon signed rank test with significant value cut off between two methods of $p<0.05$. (Gląsska et al. 2017). Correlation analysis between the means of iron intake per food group obtained from both methods using the Spearman's rank correlation, with $<0.2$ a bad outcome, 0.2 to 0.49 an acceptable outcome, and 0.5 and above is a good outcome (Lombard et al. 2015).

\section{RESULTS AND DISCUSSION}

This study involved 100 respondents who were reproductive age women in the age range of 15-49 years. Six respondents were excluded because there were changes in diet (diet and fasting) within 3 days of taking the Food Diary data. Therefore, only 94 respondents were included in the analysis.

Age characteristics and nutritional status.

Table 1 shows the general characteristics of the 
study respondents by age as well as nutritional status determined by BMI. The study respondents who were 19 years old were dominant, 32 respondents (34.04\%) and only one subject were aged 22 years old.

In this study, it is found that 52 of 94 respondents $(55.31 \%)$ had a good nutritional status, based on their body mass index, while 42 other respondents had a low body mass index that $(10.63 \%)$ and excess $(34.04 \%)$ based on WHO - Asia Pacific BMI grouping WHO (2000). The subject with body mass index (BMI) $\geq 25$ $\mathrm{kg} / \mathrm{m}^{2}$ was $17.02 \%$. This result is similar to the obesity proportion in study conducted by LopezArana et al. (2013) involving reproductive age women in 33 low income countries, that was lies between $3.4 \%$ to $73.7 \%$. The data also close to the proportion in Indonesia which is $21,8 \%$ that published in Riskesdas 2018.

Iron intake and RDA percentage. Based on this research, it was found that the daily iron intake of respondents was significantly lower than the standard proposed by the government

Table 1. Age and body mass index of respondent

\begin{tabular}{|c|c|c|}
\hline Characteristics & $\begin{array}{l}\text { Validation study } \\
\qquad(\mathrm{n}=94)\end{array}$ & $\%$ \\
\hline \multicolumn{3}{|l|}{ Age } \\
\hline 17 & 4 & 4.25 \\
\hline 18 & 23 & 24.47 \\
\hline 19 & 32 & 34.04 \\
\hline 20 & 28 & 29.78 \\
\hline 21 & 6 & 6.38 \\
\hline 22 & 1 & 1.06 \\
\hline \multicolumn{3}{|l|}{ BMI } \\
\hline $\begin{array}{l}\text { Underweight } \\
\left(<18.5 \mathrm{~kg} / \mathrm{m}^{2}\right)\end{array}$ & 10 & 10.63 \\
\hline $\begin{array}{l}\text { Normal } \\
\left(18.5-22.9 \mathrm{~kg} / \mathrm{m}^{2}\right)\end{array}$ & 52 & 55.31 \\
\hline $\begin{array}{l}\text { Overweight } \\
\left(23.0-24.9 \mathrm{~kg} / \mathrm{m}^{2}\right)\end{array}$ & 16 & 17.02 \\
\hline $\begin{array}{l}\text { Obese I } \\
\left(25.0-29.9 \mathrm{~kg} / \mathrm{m}^{2}\right)\end{array}$ & 9 & 9.57 \\
\hline $\begin{array}{l}\text { Obese II } \\
\left(>30.0 \mathrm{~kg} / \mathrm{m}^{2}\right)\end{array}$ & 7 & 7.44 \\
\hline
\end{tabular}

BMI: Body Mass Index
(MoH RI 2019). Based on Table 2, the mean daily iron intake of respondents using food diary were $10.09 \mathrm{mg}$ per day which is much lower than the RDA; only 19 respondents consumed adequate iron each day. Research by Angraini et al. (2018) reported that $95.6 \%$ subject had low iron intake while only eight out of 183 women of reproductive age had sufficient iron intake. This research data supports the importance of the currently running national program of iron and folic acid supplement for pregnant women (MoH RI 2013). Iron content-food frequency questionnaire. In this validation study, Food Diary or Weighed Food Record was used for 3 days, consisting of 2 days of weekdays and 1 day of weekends or working days. This method used by Steinemann and Grize (2017) and Głąbska et al. (2017). Filling in the questionnaire for 3 days was chosen because filling in 4 days or more can produce unfavorable results since respondents will feel tired in filling out the food diary (Thompson \& Subar 2008). Further, according to Shim et al. (2014), filling the food diary is indeed burdensome to respondents.

Table 3 shows data analysis results using the Wilcoxon signed rank test for each food group. It was found that there were no significant differences of iron intake using both methods for the meat, fish, shellfish, shrimp, and processed food groups. However, there were significant differences in several food groups for cereals, tubers, poultry, nuts, eggs, vegetables, and several other food groups. The difference between these two methods occurred due to the difficulty experienced by respondents in estimating the number of portions, because portions can differ depending on from where the food is obtained. Sauvageot et al. (2014) in their study stated that

Table 2. Iron intake and \%RDA

\begin{tabular}{llcc}
\hline $\begin{array}{c}\text { Age group } \\
\text { (years) }\end{array}$ & $\begin{array}{c}\text { Mean iron } \\
\text { intake } \\
(\mathrm{mg} / \text { day })\end{array}$ & $\begin{array}{c}\text { RDA } \\
(\mathrm{AKG} 2019) \\
(\mathrm{mg} / \text { day })\end{array}$ & $\begin{array}{c}\% \\
\text { RDA }\end{array}$ \\
\hline $16-18$ & $11.13 \pm 4.87$ & 15 & 63.21 \\
$19-29$ & $9.88 \pm 3.95$ & 18 & 51.86 \\
All & $10.19 \pm 4.18$ & & \\
\%RDA: Average of \%RDA in age group \\
RDA: Recomended Dietary Allowance
\end{tabular}




\section{Iron-food frequency questionnaire for reproductive age women}

Table 3. Food group validity measured with FFQ and FD, and difference test using wilcoxon signed rank test $\left(\mathrm{p}^{\mathrm{a}}\right)$, correlation between both methods measured with Spearman's rank correlation $\left(\mathrm{r}^{\mathrm{b}}\right)$, and it's significancy $\left(\mathrm{p}^{\mathrm{c}}\right)$

\begin{tabular}{|c|c|c|c|c|c|c|c|c|c|c|c|}
\hline \multirow[t]{2}{*}{ Food group } & \multicolumn{3}{|c|}{ FFQ iron intake } & \multicolumn{3}{|c|}{ Food diary iron intake } & \multicolumn{2}{|c|}{$\begin{array}{c}\text { Mean } \\
\text { difference } \\
\text { (FFQ-3 D FR) }\end{array}$} & \multicolumn{3}{|c|}{$\begin{array}{c}\text { Validation statistics } \\
\text { operation }\end{array}$} \\
\hline & Mean & Median & IQR & Mean & Median & IQR & Mean & $\%$ & $\mathrm{p}^{\mathrm{a}}$ & $\mathrm{r}^{\mathrm{b}}$ & $\mathrm{P}^{\mathrm{c}}$ \\
\hline $\begin{array}{l}\text { Cereals and } \\
\text { processed products }\end{array}$ & 0.36 & 0.30 & $0.22-0.46$ & 2.58 & 2.38 & $1.67-3.14$ & -2.22 & -86 & 0.000 & 0.01 & 0.889 \\
\hline $\begin{array}{l}\text { Starchy tubers and } \\
\text { processed products }\end{array}$ & 0.15 & 0.07 & $0.37-0.17$ & 0.11 & 0.00 & $0.00-0.08$ & 0.04 & 36.4 & 0.001 & 0.25 & 0.017 \\
\hline $\begin{array}{l}\text { Meats and } \\
\text { processed products }\end{array}$ & 0.18 & 0.12 & $0.07-0.20$ & 0.52 & 0.00 & $0.00-0.63$ & -0.34 & -65.4 & 0.674 & 0.10 & 0.334 \\
\hline $\begin{array}{l}\text { Poultry and } \\
\text { processed roducts }\end{array}$ & 0.26 & 0.19 & $0.12-0.28$ & 2.13 & 1.26 & $0.64-3.15$ & -1.87 & -87.8 & 0.000 & 0.07 & 0.516 \\
\hline $\begin{array}{l}\text { Fish, shellfish, } \\
\text { shrimp and } \\
\text { processed products }\end{array}$ & 0.11 & 0.08 & $0.04-0.13$ & 0.40 & 0.00 & $0.00-0.41$ & -0.29 & -72.5 & 0.314 & 0.21 & 0.047 \\
\hline $\begin{array}{l}\text { Nuts and processed } \\
\text { products }\end{array}$ & 0.17 & 0.10 & $0.05-0.25$ & 0.59 & 0.21 & $0.00-1.04$ & -0.42 & -71.2 & 0.000 & 0.25 & 0.015 \\
\hline $\begin{array}{l}\text { Eggs and processed } \\
\text { products }\end{array}$ & 0.14 & 0.12 & $0.05-0.20$ & 0.31 & 0.00 & $0.00-0.53$ & -0.17 & -54.8 & 0.028 & 0.09 & 0.354 \\
\hline $\begin{array}{l}\text { Vegetables and } \\
\text { processed products }\end{array}$ & 0.10 & 0.07 & $0.04-0.12$ & 0.87 & 0.34 & $0.00-1.11$ & -0.77 & -88.5 & 0.000 & 0.25 & 0.013 \\
\hline $\begin{array}{l}\text { Fruits and } \\
\text { processed products }\end{array}$ & 0.09 & 0.06 & $0.03-0.12$ & 0.56 & 0.21 & $0.00-0.87$ & -0.47 & -83.9 & 0.000 & 0.18 & 0.073 \\
\hline $\begin{array}{l}\text { Milk and } \\
\text { processed products }\end{array}$ & 0.30 & 0.31 & $0.06-0.62$ & 1.11 & 0.93 & $0.00-1.83$ & -0.8 & -72.9 & 0.000 & 0.21 & 0.041 \\
\hline $\begin{array}{l}\text { Fat and processed } \\
\text { products }\end{array}$ & 0.02 & 0.01 & $0.00-0.02$ & 0.02 & 0.00 & $0.00-0.00$ & 0.0 & -34.2 & 0.000 & 0.09 & 0.368 \\
\hline $\begin{array}{l}\text { Sugar, syrup, and } \\
\text { confectionary }\end{array}$ & 0.06 & 0.03 & $0.20-0.80$ & 0.90 & 0.24 & $0.00-0.80$ & -0.9 & -93.8 & 0.000 & 0.19 & 0.068 \\
\hline Spices & 0.03 & 0.02 & $0.10-0.30$ & 0.04 & 0.00 & 0.00 & 0.0 & -22.1 & 0.000 & 0.06 & 0.571 \\
\hline Beverages & 0.00 & 0.00 & 0.00 & 0.04 & 0.00 & 0.00 & 0.0 & -100.0 & 0.028 & - & - \\
\hline
\end{tabular}

FD: Food Diary; FFQ: Food Frequency Questionnaire; IQR: Inter-Quartile Range: RDA: Recomended Dietary Allowance

using photos for portion estimation can overcome this problem while in this study, no photos were used as an additional method.

Table 3 also presents the correlation coefficients obtained from the statistical operations of Spearman's rank correlation. In this validation study, the food groups of starchy tubers, fish, shellfish, and shrimp, nuts, vegetables, and milk can be accepted because they have correlation coefficients of $0.25,0.21$, $0.25,0.25$, and 0.21 respectively $(\mathrm{p}<0.05)$. These food groups were declared valid and can be used for measurement of iron intake, despite the low degree of correlation.

Aligns with Steinemann and Grize (2017), the finding could be because the food in the list was not consumed very often by respondents. In this study, the food list was obtained from the FD taken in 2017. The food has not been adapted to Jatinangor food list which has been developed since 2016. For further studies, it is necessary to update the food list so that the food types that 
are included in the FFQ are those frequently consumed and contain significant amounts of iron. The recommended list of food types that need to be included in the FFQ include common mixed food available in Jatinangor area. Some spices such as bay leaves and lemongrass, as well as beverage ingredients such as jasmine tea and cocoa powder also contain high iron per 100 grams. However, the amount of iron consumed cannot be assessed exactly because what is consumed is the water extract, not the ingredients that are listed.

Buscemi et al. (2015) in their study stated that newly designed FFQ will produce a higher correlation coefficient value compared to the questionnaire adapted from previous studies. In the same study, it was also stated that the FFQ filling method also had an effect on the correlation coefficient. The validation of the study was critically determined by the administration method of FFQ filling. Interviewer-administered method increased the correlation coefficient value, whereas in this study respondents filled out their own FFQ and it relied on their memory to complete the form.

In Table 3, almost all of the mean differences are negative. It shows that the iron intake as measured by the Iron Food Frequency Questionnaire is lower when compared to the Food Diary. This is also stated by Streppel et al. (2013) in their study which aimed to observe relative validity of FFQ, that the Food Frequency Questionnaire measures food intake is lower than the comparison method. Sauvageot et al. (2014) in their study stated that these differences could be caused by respondents' difficulty in quantifying the consumption of food and drink. Most of the food and drinks in the FFQ are served in the form of single food, but there are some types of foods that are usually consumed together with other foods or mixed dishes so that it will be difficult for respondents to estimate the frequency of their meals. In addition, the study conducted by Sauvageot also stated that filling out the FFQ depends on the memory of respondents, so that it can affect the filling of this food questionnaire. The statement was in line with what Fahmida and Dillon (2011) propose in nutritional handbook.

The limitation of this study is that this study does not perform test-retest reliability. The food list in the FFQ is also incomplete; there are some common mixed food types potential to be completed in furtherresearch. The use of photos for portion estimation is not carried out in this study, thus hindering respondents from estimating the portions they ate, and this can cause difference in measurement of FD and FFQ. The administration method that can increase the correlation coefficient results, interviewer - administered is recommended to perform in further studies.

\section{CONCLUSION}

This food questionnaire can be declared valid for measuring iron intake in the starchy tubers, fish, shellfish and shrimp, nuts, vegetables, and milk food groups because they have an acceptable correlation value. The results of measurements using the Iron Food Frequency Questionnaire are lower than the Food Diary or Weighed Food Records. Further research is needed to make adjustments to the resulting figures. It is recommended to develop FFQ data collection method with pictures guidance to help enumerators and respondents to estimate the portion size of foods and beverages to increase validity.

\section{ACKNOWLEDGEMENT}

The author would like to thank the Department of Public Health, Faculty of Medicine Universitas Padjadjaran and Department of Child Health, Faculty of Medicine Universitas Padjadjaran-Hasan Sadikin General Hospital and students of the Faculty of Medicine, Universitas Padjadjaran, batch 2016-2018 who have contributed to this research. Also, we would like to thank Putri Halleyana AR, MD for the support in proofreading this article.

\section{AUTHOR DISCLOSURES}

The authors have no conflict of interest.

\section{REFERENCES}

Angraini DI, Wijaya SM. 2018. The analysis of chronic energy malnutrition and iron intake with anemia in preconception women of childbearing age in Terbanggi Besar Subdistrict, district of Central Lampung. KnE Life Sciences. https:// knepublishing.com/index.php/KnE-Life/ 
article/view/3714/7697\#info [Accessed 18th May 2021].

Anugerah S. 2018. Frekuensi sarapan dan persentase lemak tubuh mahasiswi fakultas Rumpun ilmu kesehatan Universitas Padjadjaran [Thesis]. Bandung: Universitas Padjadjaran.

[BKKBN] Badan Kependudukan dan Keluarga Berencana Nasional. 2015. Batasan dan Pengertian MDK. Jakarta (ID): BKKBN.

[BPPK] Badan Penelitian dan Pengembangan Kesehatan. 2013. Riset kesehatan dasar (RISKESDAS) 2013. Laporan nasional 2013. https://pusdatin.kemkes.go.id/ resources/download/general/Hasil\%20 Riskesdas\%202013.pdf [Accessed 21th February 2018].

[BPS] Badan Pusat Statistik. 2020. Persentase tenaga kerja formal menurut jenis kelamin (persen) 2018-2020. BPS. https://bps. go.id/indicator/6/1170/1/persentasetenaga-kerja-formal-menurut-jeniskelamin.html [Accessed 1st July 2021].

Buscemi S, Rosafio G, Vasto S, Massenti FM, Grosso G, Galvano F, Rini N, Barlie AM, Maniaci V, Cosentino $\mathrm{L}$ et al. 2015. Validation of a food frequency questionnaire for use in Italian adults living in Sicily. Int $\mathrm{J}$ Food Sci Nutr 66(4):426-438. https://doi.org/10.3109/09 637486.2015.1025718

Fahmida U, Dillon DHS. 2011. Nutritional Assessment: Handbook. Jakarta (ID): SEAMEO RECRON UI.

Fitriananto DS, Widajanti L, Aruben R, Rahfiluddin MZ. 2018. Gambaran status gizi pekerja bangunan wanita di Kecamatan Tembalang Kota Semarang Tahun 2016. J-Kesmas 6(1):419-425.

Gibson RS. 2005. Principles of Nutritional Assessment. New York (USA): Oxford University Press.

Głąbska D, Guzek D, Ślązak J, Włodarek D. 2017. Assessing the validity and reproducibility of an iron dietary intake questionnaire conducted in a group of young Polish women. Nutrients 9(3):199. https://doi. org/10.3390/nu9030199

Hakiki G, Supriyanto S. 2018. Profil Perempuan Indonesia2018. Kementrian Pemberdayaan Perempuan dan Perlindungan Anak. Jakarta (ID): KPP, PA dan BPS.
[MoH RI] Ministry of Health Republic of Indonesia. 2013. Riset Kesehatan Dasar (RISKESDAS) Tahun 2013. Jakarta (ID): MoH RI.

[MoH RI] Ministry of Health Republic of Indonesia. 2018a. Hasil Utama Riset Kesehatan Dasar (RISKESDAS) Tahun 2018. Jakarta (ID): MoH RI.

[MoH RI] Ministry of Health Republic of Indonesia. 2018b. Profil kesehatan Indonesia 2017. MoH RI. https://pusdatin. kemkes.go.id/resources/download/ pusdatin/profil-kesehatan-indonesia/ PROFIL_KESEHATAN_2018_1.pdf [Accessed 21 th February 2018].

[MoH RI] Ministry of Health Republic of Indonesia. 2018c. Tabel komposisi pangan Indonesia. MoH RI. https://panganku.org/ id-ID/semua_nutrisi [Accessed 14th April 2019].

[MoH RI] Ministry of Health Republic of Indonesia. 2019. Peraturan Menteri Kesehatan Republik Indonesia nomor 28 Tahun 2019 tentang Angka Kecukupan Gizi yang Dianjurkan untuk Masyarakat Indonesia. Jakarta (ID): MoH RI.

Lombard MJ, Steyn NP, Charlton KE, Senekal M. 2015. Application and interpretation of multiple statistical tests to evaluate validity of dietary intake assessment methods. Nutrition Journal 14(1):1-11. https://doi. org/10.1186/s12937-015-0027-y

Lopez-Arana S, Burdorf A, Avendano M. 2013. Trends in overweight by educational level in 33 low- and middle-income countries: The role of parity, age at first birth and breastfeeding. Obesity Reviews 14(10):806-817. https://doi.org/10.1111/ obr.12051

Lopez KDS, Takemoto Y, Garcia-Casal M. , Ota E. 2018. Nutrition-specific interventions for preventing and controlling anaemia throughout the life cycle: An overview of systematic reviews. Cochrane Database Syst Rev 2018(8):1-14. https://doi. org/10.1002/14651858.CD013092

Nechitilo M, Nguyen P, Webb-GirardA, GonzalezCasanova I, Martorell R, DiGirolamo, et al. 2016. A qualitative study of factors influencing initiation and adherence to micronutrient supplementation among women of reproductive age in Vietnam. 
Food Nutr Bull 37(4):461-474. https://doi. org/10.1177/0379572116647830

Pasricha SR, Low M, Thompson J, Farrell A, De-Regil LM. 2014. Iron supplementation benefits physical performance in women of reproductive age: A systematic review and meta-analysis. J Nutr 144(6):906-914. https://doi.org/10.3945/jn.113.189589

Perdana SM, Hardinsyah H, Damayanthi E. 2014. Alternatif indeks gizi seimbang untuk penilaian mutu gizi konsumsi pangan wanita dewasa Indonesia. J Gizi Pangan 9(1). https://doi.org/10.25182/ jgp.2014.9.1.\%25p

Sauvageot N, Guillaume M, Albert A. 2013. Validation of the food frequency questionnaire used to assess the association between dietary habits and cardiovascular risk factors in the NESCAV study. J Food Sci 3(3). https://doi.org/10.4172/21559600.1000208

Shim JS, Oh K, Kim HC. 2014. Dietary assessment methods in epidemiologic studies. Epidemiol Health 36:e2014009. https://doi.org/10.4178/epih/e2014009

Steinemann N, Grize L, Ziesemer K, Kauf P, Probst-Hensch N, Brombach C. 2017. Relative validation of a food frequency questionnaire to estimate food intake in an adult population. Food Nutr Res 61(1). https://doi.org/10.1080/16546628.2017.13 05193

Streppel MT, de Vries JH, Meijboom S, Beekman M, de Craen AJ, Slagboom PE, Feskens EJ. 2013. Relative validity of the food frequency questionnaire used to assess dietary intake in the Leiden Longevity Study. Nutr J 12(1):1-8. https://doi. org/10.1186/1475-2891-12-75

Thompson FE, Subar AF. 2008. Dietary Assessment Methodology. Nutrition in the Prevention and Treatment of Disease. Third Edition. New York (USA): Elsevier Inc.

[WHO] World Health Organization. 2000. The Asia-Pacific perspective: Redefining obesity and its treatment. WHO. https://iris.wpro.who.int/bitstream/ handle/10665.1/5379/0957708211_eng. pdf [Accessed 24th May 2021]

[WHO] World Health Organization. 2021. Anaemia. https://www.who.int/healthtopics/anaemia\#tab=tab 1 [Accessed 24th May 2021].

Willett W. 1990. Nutritional Epidemiology. New York (USA): Oxford University Press. 